\title{
FACTORS INFLUENCING MEAT AND FISH CONSUMPTION IN SERBIAN HOUSEHOLDS - EVIDENCE FROM SILC DATABASE
}

\author{
Mina Kovljenić ${ }^{1}$, Mirko Savić
}

\begin{abstract}
Households buy food products, that vary from cheap to expensive, from healthy to unhealthy, from basic to value-added. Beside the nutritional, economic factors have a major and often decisive significance on a households' ability to afford certain food products. Income, price and housing costs have a significant influence on the purchase of food products. Aim of this paper is to investigate factors influencing the households' ability to afford meat or fish in a meal every other day (or a vegetarian substitute) using data from conducted Survey on Income and Living Conditions (SILC) in Serbia for the year 2013. This has been achieved by development and implementation of the logistic regression model.
\end{abstract}

Keywords: household's food demand, factors, logistic regression

JEL: $Q 19, D 12$

\section{Introduction}

Today's world is becoming more global, consumers habits are constantly changing and global companies are selling their products in all parts of the world. Agriculture is under the constant influence of the changes and challenges primarily caused by economic factors, but also by changes in consumer habits, climate change, the rise in prices, market liberalization and other factors.

One of the most dramatic changes in the world food economy, during the past 25 years is the rising role of demand-based factors in determining patterns of prices. Major demographic and economic transitions have shaped, and will continue to shape, global food systems. Two billion people have been added to the planet, over $90 \%$ in the developing world and over half of the global population now lives in cities (Naylor, 2016). By 2050 the world's population will reach 9.1 billion, 34 percent higher than today and nearly all of this population increase will occur in developing countries. Urbanization will accelerate, with about 70 percent of the

1 Mina Kovljenić M.A., Ph.D. Student of Economy, Faculty of Economics Subotica, Segedinski put no. 9-11, 24000 Subotica, Phone: +381 6454401 06, E-mail: mina.sk90@yahoo.com

2 Mirko Savić Ph.D., Full Professor, Department of Business Informatics and Quantitative Methods, Faculty of Economics Subotica, Segedinski put no. 9-11, 24000 Subotica, Phone: +38124628 018, +38121 48529 10, E-mail: savicmirko@ef.uns.ac.rs

EP 2017 (64) 3 (945-956) 
world's population expected to be urban, compared with 49 percent today. In order to feed this more urban and potentially richer population, food production will need to increase by 60 percent from the 2005-07 baseline to 2050 (FAO, 2015).

Demand for food products is determined by the needs and the ability to satisfy them. In addition to the nutritional, economic factors have a major and often decisive significance. Food prices rose sharply between 2006 and 2011, and the issue of feeding the world came to the forefront of the development agenda. Poor consumers cope with rising food prices by switching from preferred to lower-quality staples or by cutting back on relatively expensive sources of calories such as meat, fruit, and vegetables (Traill, Mazzocchi, Shankar, Hallam, 2014).

Demand for food is driven also by income growth. The marginal share of income spent on food declines with countries ranked from low to high per-capita income (Valin et al., 2014). Today, the average household in the European Union spends about $15 \%$ of their monthly income on food. This amount halved compared to 1962. A quite different situation in the Republic of Serbia, where almost half of monthly income is allocated to the purchase of food (The European Commission, 2014). The growth in income leads to a change in consumption to a more diverse diet, that includes a larger share of animal protein, fats and oils.

Today consumers buy food products, that vary from cheap to expensive, from healthy to unhealthy, from basic to value-added. Out of these, values and attitudes are important guiding forces in human life in general as well as in the food context (Hauser, Nussbeck, Jonas, 2013). However, consumption is not always an individual phenomenon, but includes social aspects such as shopping for the family, love and sacrifice, shared social cognition and feelings, influences from social norms, social identity, social situations or group influences (Olsen, Grunert, 2010).

The purpose of this paper is to reveal the impact of household income and living conditions on the purchase of food product. The goal is to discover the main factors that affect the demand for food products. Demand is presented through the ability of household to afford meat or fish in a meal every other day (or a vegetarian substitute). Food prices and food affordability (defined here, in broad terms, as the cost of the diet of a household relative to the household's income) are important determinants of food choices, dietary patterns, nutrition and health (Lee et al., 2013). Through the analysis of demand for food products provides the parameters for explanation of food consumption patterns and probable nutritional changes in the dynamic economic environment. On the basis of data from Survey on Income and Living Conditions (SILC) for the year 2013, we have developed the econometric model which is going to predict the households ability to afford meat or fish in a meal every other day (or a vegetarian substitute), on the basic of socio-economic and other factors.

\section{Literature overview}

Agriculture has succeeded so far to respond globally to increased food demand. Food supply has more than tripled since the 1960s and continues to rise everywhere (Valin et al., 2014). Households demand for food products is determined by the needs and the ability to satisfy them. 
Household spending on food tends to increase as income levels increase, but the proportion of total income devoted to food declines. As incomes rise in lower income countries, their food expenditures grow and consumption patterns appear to seek to catch up to the levels and composition of those of higher income countries (Regmi, Meade, 2013). In low-income countries, expenditure on foods can take up to $62 \%$ of income, and in middle-income and high-income countries, people spend on average much less on foods (6-30\% of their income) (Gao, 2012). In the middle-income and high-income countries, a similar increase in food prices is likely to have a much smaller impact on consumption.

Demand for food variety rises quickly, as income levels rise. The share of income spent on cereals, fruits and vegetables decreases, while spending on other foods, such as prepared/ convenience foods and beverages increases (Herforth, Ahmed, 2015). Income growth generates a shift toward animal products and a larger demand for processed products and food away from home, especially in the transition between low and middle income levels. On the other hand, at higher income levels, demand for luxury goods (including health) becomes more prominent, and consumption of meat and fats is reduced (Traill, Mazzocchi, Shankar, Hallam, 2014).

Except income, price also has a significant influence on the purchase of food products. The increasing real price of food is likely to cause significant changes in diets and nutrient intake. In the poor countries households cope with rising prices by switching to low-quality, cheaper, staple foods, reduction in overall food intake, decrease in the consumption of nutrient rich non-staples, and an increase in the consumption of cheaper, high-calorie but low-nutrient 'street' food. Food consumption was most sensitive to changes in prices in low-income countries, with the highest own-price elasticity estimates found for meat, fish and dairy. On the other hand, consumption of cereals, and fats and oils is least sensitive to changes in prices. As calories from cereals make up approximately half of all calories available in low-income countries, an increase in cereal prices would have a bigger impact on diet relative to price increases in other foods (Cornelsen et al., 2015).

High housing costs can also affect the demand for food. Housing costs are among the most significant expense in a household balance. Thus, high housing costs may cause households to reduce non-housing expenditures such as health care, education, food and clothing. The gap between housing expenditures and income in some cases can lead to changes in diet. Housing costs may significantly reduce households' willingness to spend, affecting households' disposable income and lowering their standard of living. On the other hand, housing costs can be to some extent mitigated if households are owners rather than renters (Deidda, 2015). Household total expenditure (consumption) is very important phenomenon in many research areas. It is desirable to have information on household total expenditure (consumption), because this information can be used for tracking changes in the distribution of material living standards over time, consumption and saving research, the use of consumption as a conditioning variable in life cycle models and many other uses (Savic, 2007).

Scientific literature in the area of factors affecting the demand for food is very rich, with increasing number of papers, studies and books considering the food demand. In the next 
section are listed some of the authors who have dealt with investigations of factors that influence the demand for food products.

Vinnari et al. (2010) paper aims to examine changes in household consumption behaviour through an empirical investigation of the decision to consume meat, to not consume meat or to consume only small amounts of meat. The analysis revealed that the decision not to consume meat became prevalent in Finland at the end of the 1970s but the growth rate has somewhat stabilised during recent decades. The gender of the highest earner in the household affects the family meat consumption. As non-meat consumption has become more widespread it has also more clearly become a middle-class phenomenon.

Matz et al. (2015) study investigated the impact of food price changes on food security in urban and rural Ethiopia. The results indicated that increases in cereal prices are generally, but not always, associated with households having a lower number of meals and switching to less preferred foods.

Griffith et al. (2015) documented the changes in the relative prices of different food groups. In the paper they used a demand model to isolate the impact that these changes had on the food purchases of a panel of British households. The results suggest that over time period there was a complex interplay of factors, including changes in prices and preferences, which led to households altering their food purchasing behaviour.

Zhou et al. (2015) paper provides empirical insights about what and how factors affect household fish consumption in China. In the paper they combined Multiple Correspondence Analysis method and Marshallian demand model. Their research reveals that for all households, pork is still a main substitution of fish, and fish consumption differs a lot between provinces. For households with higher dietary knowledge, the authors found that increase of income, the existence of adolescent causes an increase in fish consumption, while illness of household member makes a decrease in fish consumption.

Harttgen et al. (2016) paper analyzed how changes in prices of specific food groups, such as maize prices or prices for staple foods, as well as how negative short-term household level income shocks affect the entitlements to calorie consumption of individuals and how these changes affect overall food poverty. They used household survey data from Malawi. According to their results price shocks for staple foods have a considerable impact on food security with particularly strong effects on poor net food buyers in rural and urban areas.

Roux et al. (2000) study was carried out on 657 people in three different regions of France, and the aim was to identify different "food strategies" among sub-groups of this population, who were faced with financial difficulties. The statistical analysis used was a Correspondence Factorial Analysis. The average food budget was $27 \%$, that was the amount of money the people estimated they spent monthly on food compared with the sum of their disposable income. The results showed, that in absolute terms, the food expenditure of low-income populations remains lower than that of the better-off. The main food groups were consumed less frequently overall than in the general population, notably fresh fruit and vegetables. Consumption of some fresh products like dairy foods and meat were acceptable in terms of 
healthy eating recommendations.

In the United States Food assistance programs has provided low-income households with the resources to purchase a healthy diet, if they buy the market baskets of food outlined in the Thrifty Food Plan. Stewart and Blisard (2006) study showed that married couples with children and female-headed households with children have spent only $73 \%$ and $82 \%$, respectively, and just $43 \%$ and $50 \%$ for at-home fruits and vegetables. In contrast to the average, food at-home spending by low-income households averages about $86 \%$ of the TFP (Thrifty Food Plan) cost of foods versus $118 \%$ for the highest income households. While low-income households have spent about (more than) the TFP amount on at-home cereal and bakery goods, they spent just $53 \%$ on at-home fruits and vegetables, $70 \%$ on at-home meat, poultry, fish, and eggs, and $74 \%$ on at-home dairy products.

From the listed literatures, it could be seen that besides income and price, household characteristics and household costs play a important role in decision making of food consumption.

\section{Material and method}

Recognizing the importance of households' demand for food products, quantitative analysis in this paper will focus on building up an econometrics model for predicting households demand for food products in Republic of Serbia.

Quantitative analysis was performed using SILC databases for Republic of Serbia. Main goal of SILC research is to investigate income distribution and social exclusion. The survey was conducted on the territory of the Republic of Serbia in 2013 and in the sample 8008 households took part.

Survey on Income and Living Conditions (SILC) is an annual, sample survey which provides data on income, poverty, social exclusion and living conditions. Social exclusion and housingcondition information is collected at household level. At household level, four domains are covered: basic data, housing, material deprivation and income. The personal level is regrouped into five domains: basic/demographic data, education, health, labour and income.

Determining the factors influencing the demand for food products is essential. Previous studies on demand for food products indicate the existence of a significant correlation between demand for food products on one side and demographic characteristics, educational structures and income distribution on the other. Household expenditures, financial situation of a household, number of household members are just some of the factors that can also affect the demand for food products, and which we analyze in this paper.

The aim of further analysis is to assess the prediction of households' ability to afford meat or fish in a meal every other day (or a vegetarian substitute) by performing binary logistic regression model.

Logistic regression model represents a statistical method for predicting the outcome of categorical dependent variable based on one or more independent variables that are called 
predictors. When observed outcome for dependent variable has two possible options, model is called binary logistic regression model. Through logarithmic relationship possible outcomes of dependent variable are modeled by probabilities as a function of the predictors (Savic, Kresoja \& Zivadinovic, 2015). Method in which all predictors enter the equation simultaneously is chosen. Dependent variable is coded in the following manner. It takes value 1 if the household is able to afford meat or fish in a meal every other day (or a vegetarian substitute) and takes value 0 if the household is not able to afford meat or fish in a meal every other day (or a vegetarian substitute). This way, households are classified into two groups. Using logistic regression, effects of various different factors on probability to afford certain food in these two groups are estimated for all households separately.

Table 1. $Y$ codes

\begin{tabular}{|c|c|c|}
\hline $\begin{array}{c}\text { Households' ability to afford meat } \\
\text { or fish in a meal every other day } \\
\text { (or a vegetarian substitute) }\end{array}$ & Y codes & Percent of households \\
\hline Yes & 1 & $66.79 \%$ \\
\hline No & 0 & $33.21 \%$ \\
\hline
\end{tabular}

Source: Authors presentation based on SILC database

\section{Results of research and discussion}

In the next section the results of the research will be shown.

Model is used on the basis of total 6 available predictors: 1 social-demographic predictor, 5 predictors all related to income and living conditions. Detailed list of independent variables and coding for all categorical predictors is specified in the following table.

Social-demographic predictors and predictors related to household ability to afford meat or fish in a meal every other day (or a vegetarian substitute) are presented in the next table.

Table 2. Variables included in model

\begin{tabular}{|c|c|c|c|}
\hline No. & Variable & Categories & Name \\
\hline 1 & $\begin{array}{l}\text { The total number of } \\
\text { household members }\end{array}$ & & HMembers \\
\hline \multirow{3}{*}{2} & \multirow{3}{*}{$\begin{array}{l}\text { Are you or any of your } \\
\text { household members } \\
\text { owner of the apartment } \\
\text { where you live or rent it? }\end{array}$} & 1 Yes, owner & \multirow{3}{*}{ Owner } \\
\hline & & $\begin{array}{l}2 \text { Yes, but repaying the loan } \\
3 \text { The lessee all or part of the apartment, the } \\
\text { rent after market conditions }\end{array}$ & \\
\hline & & $\begin{array}{l}4 \text { Tenant who pays the rent at a price lower } \\
\text { than the market } \\
5 \text { Accommodation is free }\end{array}$ & \\
\hline \multirow[b]{2}{*}{3} & \multirow{2}{*}{$\begin{array}{l}\text { Do you pay off the loan } \\
\text { by whom you purchased } \\
\text { the flat/house in which } \\
\text { you live? }\end{array}$} & 1 Yes & \multirow[b]{2}{*}{ Loan } \\
\hline & & 2 No & \\
\hline
\end{tabular}




\begin{tabular}{|c|c|c|c|}
\hline \multirow[b]{2}{*}{4} & \multirow[b]{2}{*}{$\begin{array}{l}\text { To what extent total } \\
\text { housing cost impact your } \\
\text { household budget? }\end{array}$} & 1 Significantly, the burden & \multirow[b]{2}{*}{ HCost } \\
\hline & & $\begin{array}{l}2 \text { To some extent the burden } \\
3 \text { Not encumbered by general }\end{array}$ & \\
\hline \multirow[b]{4}{*}{5} & \multirow{4}{*}{$\begin{array}{l}\text { When you think about } \\
\text { total income for your } \\
\text { household, do you feel } \\
\text { that your household is } \\
\text { able to make ends meet, } \\
\text { namely to pay their } \\
\text { necessary expenses? }\end{array}$} & 1 Very hard & \multirow[b]{4}{*}{ Ability } \\
\hline & & 2 Hard & \\
\hline & & 3 With some difficulty & \\
\hline & & $\begin{array}{l}4 \text { Quite easy } \\
5 \text { Easy } \\
6 \text { Very easy }\end{array}$ & \\
\hline \multirow{4}{*}{6} & \multirow{4}{*}{$\begin{array}{l}\text { Has your household } \\
\text { produced in } 2012 \text { some } \\
\text { of these products for own } \\
\text { needs: grains? }\end{array}$} & $1 \mathrm{Yes}$ & \multirow{4}{*}{ Grains } \\
\hline & & $2 \mathrm{No}$ & \\
\hline & & & \\
\hline & & & \\
\hline
\end{tabular}

Source: Authors presentation

Model 1 (software output): Logit, using observations 1-8007 $(\mathrm{n}=1659)$

Missing or incomplete observations dropped: 6348

Dependent variable: Afford

Standard errors based on Hessian

\begin{tabular}{|l|c|c|c|c|l|}
\hline & Coefficient & Std. Error & $z$ & $p$-value & \\
\hline const & 0.648574 & 2.23186 & 0.2906 & 0.7714 & \\
\hline HMembers & 0.219545 & 0.0347325 & 6.3210 & $<0.0001$ & $* * *$ \\
\hline Loan & -1.36656 & 1.10206 & -1.2400 & 0.2150 & \\
\hline HCost & 0.559208 & 0.146623 & 3.8139 & 0.0001 & $* * *$ \\
\hline Ability & 0.898647 & 0.0859576 & 10.4545 & $<0.0001$ & $* * *$ \\
\hline Grains & -0.130428 & 0.125456 & -1.0396 & 0.2985 & \\
\hline
\end{tabular}

\begin{tabular}{|l|r|l|l|r|}
\hline Mean dependent var & 0.711272 & & S.D. dependent var & 0.453308 \\
\hline McFadden R-squared & 0.145910 & & Adjusted R-squared & 0.139893 \\
\hline Log-likelihood & -851.5904 & & Akaike criterion & 1715.181 \\
\hline Schwarz criterion & 1747.665 & & Hannan-Quinn & 1727.221 \\
\hline
\end{tabular}


Model 1 (software output): Number of cases 'correctly predicted' $=1222(73.7 \%)$ $\mathrm{f}($ beta' $\mathrm{x})$ at mean of independent vars $=0.453$

Likelihood ratio test: Chi-square(5) $=290.967$ [0.0000]

Slope $^{*}$
0.0400816
-0.249489
0.102093
0.164063
-0.0238118

$\wedge$ Afford $=0.649+0.220 *$ HMembers $-1.37 *$ Loan $+0.559 *$ HCost $+0.899 *$ Ability $0.130 *$ Grains
(2.23) (0.0347)
$(0.147)$
$(0.0860)$
$(0.125)$

$\mathrm{n}=1659$, R-squared $=0.146$

(standard errors in parentheses)

Binary logistic regression model shows that on the households' ability to afford meat or fish in a meal every other day (or a vegetarian substitute) significant influence have the following variables: number of household members, household expenses and the ability of household to make ends meet, namely to pay their necessary expenses. Households with more members, lower impact of total housing cost on household budget and lower households' difficulty to pay their necessary expenses are more likely to be able to afford meat or fish in a meal every other day (or a vegetarian substitute). For these independent variables p-value is less than $\alpha(0,01)$, hypothesis Ho is rejected and there is a significant connection between the listed independent variables and the dependent variable.

Variable owner was ejected from the model due to existence of multicollinearity with variable loan.

McFadden coefficient of determination shows that $14.59 \%$ of variations in households' ability to afford meat or fish in a meal every other day (or a vegetarian substitute) is explained by the variations of the independent variables of the model.

Number of correct predicted outcome is $73.7 \%$. Based on Likelihood ratio test the conclusion is that the whole model is statistically significant.

With an increase in the number of household members probability that household will afford meat or fish in a meal every other day (or a vegetarian substitute) increases by $4 \%$ on average.

With the decrease of total housing cost impact on household budget probability that household will afford meat or fish in a meal every other day (or a vegetarian substitute) increases by 10.2 $\%$ on average.

With the decrease of households' difficulty to pay their necessary expenses probability that household will afford meat or fish in a meal every other day (or a vegetarian substitute) increases by $16.4 \%$ on average. 


\section{Conclusion}

Understanding factors that affect future food demand capacity is an important component of strategic planning to reduce food insecurity. Household expenditures, financial situation of a household, number of household members represent the factors that can affect the demand for food products. The share of income or households consumption expenditure spent on food is often used as an indicator for the relative well-being of a country.

Examination of food demand patterns over time and how these patterns adjust to rising incomes, households costs and changing prices enables better projection of food needs. It provides an insight into the kinds of food households are likely to buy in the future. Also it allows identification of at-risk populations, and improves predictions about how the food industry may be structured to meet the evolving trends in global demand.

On the basis of logistic analysis, we have discovered three statistically significant factors influencing meat and fish consumption. These factors are: number of household members, households' cost and ability of household to pay necessary expenses. Increase in the number of household members, decrease in the total housing costs and decrease of households' difficulty to pay their necessary expenses increases the probability that household will afford meat or fish in a meal every other day (or a vegetarian substitute).

The main limitation of the research include problems associated with: objectivity of answers and insufficient coverage of research (not included some important variables such as income of households, price of meat and fish, household spending on food).

In our research only a few variables were taken for analysis, but this is just a start for further and more detailed scientific research. The next step in our research will be expansion of our model with new potential factors like income of households, price of meat and fish, household spending on food and their influence on the meat and fish consumption. Further research could also include personal information such as basic/demographic data, education, health, labour and investigate how these variables influence meat and fish consumption. Deeper processing of these answers, would get results that are not covered in this paper.

\section{Literature}

1. Cornelsen, L., Green, R., Turner, R., Dangour, A. D., Shankar, B., Mazzocchi, M., Smith, R. D. (2015): What happens to patterns offood consumption when food prices change? Evidence from a systematic review and meta-analysis of food price elasticities globally. Vol. 24, pp. 1548-1559, Health Economics, Wiley, USA.

2. Deidda, M. (2015): Economic Hardship, Housing Cost Burden and Tenure Status:Evidence from EU-SILC, Journal of Family and Economic, Issue 36, pp. 531556, Springer US, USA.

3. FAO (Food and Agriculture Organization) (2015): The State of Agricultural Commodity Markets, (available at: http://www.fao.org/3/a-i5090e.pdf).

4. Gao, G. (2012): World food demand. American Journal of Agricultural Economics, Vol. 94, pp. 25-51, Agricultural and Applied Economics Association, Milwaukee.

EP 2017 (64) 3 (945-956) 
5. Griffith, R., O'Connell, M., Smith, K. (2015): Relative prices, consumer preferences, and the demand for food. Oxford Review of Economic Policy, Vol. 31, No. 1, pp. 116-130, Oxford Academic, Oxford, UK.

6. Hauser, M., Nussbeck, F., W., Jonas, K. (2013): The Impact of Food-Related Values on Food Purchase Behavior and the Mediating Role of Attitudes: A Swiss Study. Psychology and Marketing, Vol. 30, No. 9, pp. 765-778, Wiley, USA.

7. Harttgen,K., Klasen, S., Rischke, R. (2016): Analyzing nutritional impacts of price and income related shocks in Malawi: Simulating household entitlements to food. Food Policy, Vol. 60, pp. 31-43, Elsevier B.V., Amsterdam, The Netherlands.

8. Herforth, A., Ahmed, S. (2015): The food environment, its effects on dietary consumption, and potential for measurement within agriculture-nutrition interventions. Food Security, Vol. 7, Issue 3, pp. 505-520, Springer US, USA.

9. Lee, A., Mhurchu, C. N., Sacks, G., Swinburn, B., Snowdon, W., Vandevijvere, S., Hawkes, C., L Abbe, M., Rayner, M., Sanders, D., Barquera, S., Friel, S., Kelly, B., Kumanyika, S. Lobstein, T., Ma, J., Macmullan, J., Mohan, S., Monteiro, C., Neal, B., Walker, C. (2013): Monitoring the price and affordability of foods anddiets globally. Obesity Reviews, pp. 82-95, John Wiley \& Sons Ltd, USA.

10. Matz, J. A., Kalkuhl, M., Abegaz, G. A. (2015): The short-term impact of price shocks on food security-Evidence from urban and rural Ethiopia. Food Security, Vol. 7, Issue 3, pp. 657-679, Springer US, USA.

11. Naylor, R. L. (2016): Oil crops, aquaculture, and the rising role of demand: A fresh perspective on food security. Global Food Security, Vol. 11, pp. 1-9, Elsevier B.V., Amsterdam, The Netherlands.

12. Olsen, S. O., Grunert, G. K. (2010): The role of satisfaction, norms and conflict in families'eating behavior. European Journal of Marketing, Vol. 44 Issue 7/8, pp. 1165 - 1181, Emerald, England.

13. Regmi, A., Meade, B. (2013): Demand side drivers of global food security. Global Food Security, Vol. 2, pp. 166-171, Elsevier B.V., Amsterdam, The Netherlands.

14. Roux, C., Couedic, P. L., Durand-Gasselin, S. (2000): Consumption patterns and food attitudes of a sample of 657 low-income people in France. Food Policy, Vol. 25, pp. 91-103, Elsevier B.V., England.

15. Savić, M. (2007): Questions about household consumption in surveys. Panoeconomicus, Vol. 54, Issue 3, pp. 347-357, Savez ekonomista Vojvodine, Novi Sad, Srbija.

16. Savić, M., Kresoja, M., Živadinović, I. (2015): Social Dimension of International Student Mobility in Bosnia and Herzegovina, Montenegro and Serbia. Finding the right path Higher education financing and social dimension in the Western Balkan countries, University of Belgrade, Beograd, pp. 165-185.

17. Stewart, H., Blisard, N. (2006): The Thrifty Food Plan and low-income households in the United States: What food groups are being neglected? Food Policy, Vol. 31, pp. 469- 
482, Elsevier B.V., England.

18. Traill, W. B., Mazzocchi, M., Shankar, B., Hallam, D. (2014): Importance of government policies and other influences in transforming global diets. Nutrition Reviews, Vol. 72, No. 9, pp. 591-604, Wiley, USA.

19. The European Commission, Directorate-General for Communication, (2014): The policies of the European Union: Agriculture, (available at: http://europa.eu/pol/pdf/flipbook/ hr/agriculture hr.pdf).

20. Valin, H., Sands, R. D., Mensbrugghe, D., Nelson, G.,C., Ahammad, H., Blanc, E., Bodirsky, B., Fujimori, S., Hasegawa, T., Havlik, P., Heyhoe, E., Kyle, P.,Croz, D., M., Paltsev, S., Rolinski, S., Tabeau, A., Meijl, H., Lampe, M., Willenbockel, D. (2014): The future of food demand: understanding differences in global economic models. Agricultural Economics, Vol. 45, pp. 51-67, International Association of Agricultural Economists, Wiley, USA.

21. Vinnari, M., Mustonen, P., Rasanen, P. (2010): Tracking down trends in non-meat consumption in Finnish households, 1966-2006. British Food Journal, Vol. 112 Issue 8, pp. 836-852, Emerald, England.

22. Zhou L., Jin S., Zhang B., Cheng G., Zeng Q., Wang, D. (2015): Determinants of fish consumption by household type in China. British Food Journal, Vol. 117, Issue 4, pp. 1273-1288, Emerald, England. 


\title{
FAKTORI OD UTICAJA NA POTROŠNJU MESA I RIBE U \\ DOMAĆINSTVIMA U SRBIJI - PODACI IZ SILC BAZE PODATAKA
}

\author{
Mina Kovljenic ${ }^{3}$, Mirko Savic ${ }^{4}$
}

\begin{abstract}
Apstrakt
Domaćinstva kupuju prehrambene proizvode, koji varijariju od jeftinih do skupljih, od organskih do neorganskih, od osnovnih do onih sa dodatnom vrednošću. Osim prehrambenih, ekonomski faktori imaju veliki $i$ često odlučujući uticaj na mogućnost domaćinstava da priušte određene prehrambene proizvode. Prihodi, cene i stambeni troškovi imaju značajan uticaj na kupovinu prehrambenih proizvoda. Cilj ovog rada je otkrije faktore koji utiču na sposobnost domaćinstava da priušte meso ili ribu u obroku svaki drugi dan (ili vegetarijansku zamenu) koristeći podatke iz sprovedene Anketa o prihodima $i$ životnim uslovima (SILC) u Srbiji za 2013. godinu. Ovo je postignuto razvojem i implementacijom modela logističke regresije.
\end{abstract}

Ključne reči: tražnja za hranom u domaćinstvu, faktori, logistička regresija

3 Mina Kovljenić M.A., doktorant ekonomije, Ekonomski fakultet u Subotici, Segedinski put br. 9-11, 24000 Subotica, Telefon: +38164544 01 06, E-mail: mina.sk90@yahoo.com

4 Redovni profesor, dr Mirko Savić, Departman za poslovnu informatiku i kvantitativne metode, Ekonomski fakultet u Subotici, Segedinski put br. 9-11, 24000 Subotica, Telefon: +381 24 628-018, 021/485-2910, E-mail: savicmirko@ef.uns.ac.rs 